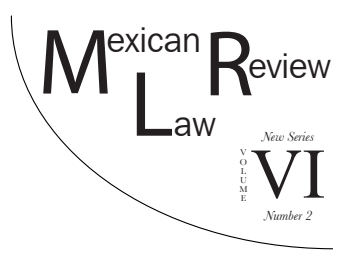

\title{
MIGRATION OF RESPONSIBILITY: THE TRUST DOCTRINE AND THE TOHONO O'ODHAM NATION
}

\author{
Karrie A. GuRbaCKI*
}

\begin{abstract}
This article discusses the impact of the influx of migrants from Mexico and Central America on the American Southwest. Specifically, it discusses how Native American tribes of the Southwest, especially the Tohono O'odham Nation, have become a magnet for illegal border crossings due to lax enforcement policies on tribal land. As a result, the tribe has encountered a surge in drug-trafficking, violence, and environmental destruction on its reservation. The article first analyzes the trust doctrine between the Native American tribes and the United States federal government. It concludes with a discussion of the monetary and equitable relief available to the Tohono O'odham Nation in the form of damage awards and increased border protection.
\end{abstract}

Key Words: Immigration, Tohono-O'odham Nation, Native American tribes, US-Mexico relations, tribal sovereignty, trust doctrine, American Southwest.

RESUMEN. En este artículo se analiza el impacto de la afluencia de inmigrantes de México y América Central en el suroeste de Estados Unidos. En particular, se analiza cómo las tribus nativas norteamericanas, especialmente la nación Tohono O'odham, que viven en el suroeste se han convertido en un imán para los cruces ilegales de la frontera debido a las políticas de aplicación laxa en tierras tribales. Como resultado, la tribu ha detectado un aumento en el tráfico de drogas, la violencia y la destrucción del medio ambiente en su reservación. El artículo analiza la doctrina de la confianza entre las tribus de nativos americanos y el gobierno federal de los Estados Unidos, y concluye con una discusión de las reparaciones pecuniarias y equitativas a disposición de la nación Tohono O'odham, si desean recuperarse de los daños sufridos por los migrantes y fomentar más patrulla fronteriza.

PaLABRAS Clave: Inmigración, nación Tohono-O'odham, tribus americanas nativas, relaciones México-Estados Unidos, soberanía tribal, doctrina de la confianza, sudoeste americano.

* Juris Doctorate Candidate May 2014, Villanova University School of Law; Bachelor of Arts Political Science and Bachelor of Arts International Relations, State University of New York at Geneseo. 
I. INTRODUCTION

1. The Immigration Crisis 274

2. Who Are the Tohono O'odham?....

3. The Tohono O'odham Nation: Victims of Migrants.... 277

II. Analyzing Tohono O’odham Claims Against the Federal Government

1. Statutory Claims for Property Damage 282

2. The Guardian Ward Relationship: Common Law Trust and Protection Claim.

\section{INTRODUCTION}

\section{The Immigration Crisis}

For many Americans living in the Southwest, the increase in the flow of illegal immigrants over the past decade has been a significant disruption. For the Tohono O'odham Nation, which partially spans the border of Mexico and Arizona, such trends spell possible disaster for the survival of the Tribe.

Throughout our nation's history, immigration has played a vital role in the development and advancement of American society. ${ }^{1}$ Since 2007, when illegal migrants outnumbered those who came here legally for the first time in American history, ${ }^{2}$ the number of illegal crossings has decreased. Clearly, immigration still remains a problem reflected by $\$ 18$ billion spent on immigration enforcement, more than all federal law enforcement agencies combined. ${ }^{3}$ Fortunately, both political parties are moving in the direction of

${ }^{1}$ See Michal Czerwonka, Immigration and Emigration, The New York Times, Feb. 26, 2013, http://topics.nytimes.com/top/reference/timestopics/subjects/i/immigration-and-emigration/index.html.

2 See id. The current wave of immigration is the largest since the 1920s. For example, in 2007, 12 million illegal immigrants entered the United States. See also Carolina Moreno, Border Crossing Deaths More Common as Illegal Immigration Declines, The Huffington Post, Feb. 26, 2013, http://www.huffingtonpost.com/2012/08/17/border-crossing-deaths-illegal-immigra tion_n_1783912.html. In 2011,327,577 migrants attempted to cross the border illegally; a decline from 858,638 in 2007. However, death rates have increased, as 368 out of 327,577 people were discovered in 2011 compared to 398 out of 858,638 in 2007.

3 See Julia Preston, Huge Amounts Spent on Immigration, Study Finds, The New York Times, Jan. 7, 2013, http://www.nytimes.com/2013/01/08/us/huge-amounts-spent-on-immigration-stu dy-finds.html?_r=0 (According to a report published Monday by the Migration Policy Institute, a nonpartisan research group in Washington). 
comprehensive immigration reform. ${ }^{4}$ The immigration debate was brought to the forefront of national media when President Obama won 71 percent of the Hispanic vote in the 2012 presidential election. ${ }^{5}$ Although the issue has remained a priority on Obama's agenda, Congress has yet to pass a comprehensive overhaul. ${ }^{6}$ Ideally, Obama seeks to first tighten border control and subsequently establish a path to citizenship for the eleven million illegal immigrants currently residing in the United States.

In Arizona, where part of the Tohono O'odham Nation resides, the Supreme Court recently struck down parts of Arizona's SB 1070, Arizona's tough law on illegal immigrants, but left intact a controversial provision requiring police to check the immigration status of people detained and suspected of being in the country illegally. ${ }^{8}$ In a later District Court decision concerning the enforcement of the ruling, however, the Court ordered the state to stop enforcing a provision that makes it a crime to transport illegal immigrants inter-state. ${ }^{9}$ This move ensured that federal legislation would remain at the forefront for immigration reform, as the decision held that "states cannot impose rules in areas already regulated by federal immigration laws." In effect, the Arizona law and the Supreme Court decision enhanced local

${ }^{4}$ See Cizerwonka, supra note 1. In fact, "President George W. Bush for three years pushed for a bipartisan immigration reform bill before giving up in 2007, blocked by conservative opposition."

${ }^{5}$ See id. Mitt Romney won just 27 percent. Those results received much media attention, particularly among Republicans who were concerned that the outcome would be an issue in future elections.

${ }^{6}$ See Czerwonka, supra note 1.

${ }^{7}$ See id. Obama has stated that the pathway to citizenship hinges on progress in securing the border. He has indicated that he prefers to work with Congress, rather than propose his own legislation.

${ }^{8}$ See Robert Barnes, Supreme Court Upholds Key Part of Arizona Law for Now, Strikes Down Other Provisions, The Washington Post, June 25, 2012, http://articles.washingtonpost.com/201206-25/politics/35461864_1_immigration-decision-arizona-law-illegal-immigrants. The court held that the following is unconstitutional: the "state cannot make it a misdemeanor for immigrants to not carry registration documents; criminalize the act of an illegal immigrant seeking employment; or authorize state officers to arrest someone on the belief that the person has committed an offense that makes him deportable."

9 See Fernanda Santos, Arizona Immigration Law Survives Ruling, The New York Times, Sept. 6, 2012, http://www.nytimes.com/2012/09/07/us/key-element-of-arizona-immigration-lawsurvives-ruling.html?_r=0 (stating victory for plaintiffs).

${ }^{10}$ Id. As Justice Kennedy stated, "Arizona may have understandable frustrations with the problems caused by illegal immigration while that process continues, but the state may not pursue policies that undermine federal law." See id. (quoting Supreme Court). See also Fernanda Santos, Arizona Immigration Law Survives Ruling, The New York Times, Sept. 62012 (reporting judge "employed the same rationale used by the courts in Alabama and Georgia to block similar provisions"). 
authority to combat illegal immigration provided it remains within Constitutional limitations. ${ }^{11}$

\section{Who Are the Tohono O'odham?}

Historically, the Tohono O'odham Nation occupied much of the American southwest. ${ }^{12}$ From the early eighteenth century on, however, Tohono O'odham tribal lands have been occupied by the United States and Mexico. ${ }^{13}$ When Mexico gained its independence, it officially asserted rule over the Tribe. ${ }^{14}$ Through the Gadsden Purchase in 1853, the Tohono O'odham land was divided into American and Mexican sectors. ${ }^{15}$ This agreement continued until the United States created a reservation for the Tohono O'odham in 1974 by executive order. ${ }^{16}$

Today, the Tohono O'odham Nation shares a border with Mexico for 63 miles; about $17 \%$ of the Arizona-Mexico border. ${ }^{17}$ There are about nine Tohono O'odham communities that lie south of the American border. ${ }^{18}$ In the United States, the main reservation is located in Southwestern Arizona near Tucson. ${ }^{19}$ In total, the reservation is almost 4,500 square miles, making it the third largest in the United States at about the size of Connecticut. ${ }^{20}$ Accord-

${ }^{11}$ See id. As Obama said, "Going forward, we must ensure that Arizona law enforcement officials do not enforce this law in a manner that undermines the civil rights of Americans, as the Court's decision recognizes."

${ }^{12}$ See The Official Website of the Tohono O'odham Nation: History and Culture, http://www.tonation-nsn.gov/default.aspx. "The O'odham inhabited an enormous area of land in the southwest, extending South to Sonora, Mexico, north to Central Arizona, and west to the Gulf of California, and east to the San Pedro River. This land base was known as the Papagueria and it had been home to the O'odham for thousands of years."

${ }_{13}$ See The Official Website of the Tohono O'odham Nation: History and Culture.

14 See id.

${ }^{15}$ See id. The treaty was aimed at resolving border disputes after the end of the MexicanAmerican War. However, the treaty has been highly criticized as American imperialistic behavior by forcing Mexico to sell the land to aid in the United States' effort at building a transcontinental railroad. See Ignacio Ibarra, Land Sale Still Thorn to Mexico, Arizona Daily Star, Feb. 122004.

${ }^{16}$ See John Dougherty, One Nation, Under Fire, High Country News, Feb. 19, 2007.

${ }^{17}$ See Susan Bradford, Illegal Immigration from the Perspective of Arizona's Tohono O'odham Nation, Aug. 26, 2010, http://susanbradfordpress.wordpress.com/2010/08/26/illegal-immigrationfrom-the-perspective-of-arizonas-tohono-oodham-nation/. See also Amanda Crawford, Arizona's State-Owned Mexico Border Fence Attracts Donors from Across U.S., Aug 2, 201 1, http://www. bloomberg.com/news/2011-08-02/arizona-s-state-owned-mexico-border-fence-attracts-donors-from-across-u-s-.html/.

18 See id.

19 See id. (Reporting that the total non-contiguous segments amount to more than 2.8 million acres).

${ }^{20}$ See id. (Noting reservation is also second largest in Arizona). 
ing to the 2000 U.S. census, 10,201 people live on the reservation..$^{21}$ According to Tribal estimates, however, there are 28,000 tribal members living on reservation land in Arizona..$^{22}$ It is estimated that only about 1,500 tribal members reside in Mexico. ${ }^{23}$ Unfortunately, most Tribe members live in poverty, with unemployment hovering around 42 percent; about 40 percent live below poverty level with a per capita income of $\$ 8,000 .{ }^{24}$

\section{The Tohono O'odham Nation: Victims of Migrants}

After the September $11^{\text {th }}$ attacks and the resulting surge in border security, illegal migrants from Mexico have exploited the Tohono O'odham reservation, due to its relatively weaker border security, as the federal government has yet to implement the same technology on the reservation as it has along other parts of the border. ${ }^{25}$ There is also evidence that, knowing that the Nation opposed humanitarian aid to migrants, the U.S. government increased border security on either side of Tribal lands more than on Tribal lands, creating a funnel effect that forces migrants to cross through the reservation. ${ }^{26}$ There is also some evidence that the reservation bears the brunt of migrant crossings even within Arizona, which has by far more crossings than any other part of the state. ${ }^{27}$ As a result, the reservation finds itself at the crossroads of

${ }^{21}$ See The American Indian and Alaska Native Population: 2010, Census Briefs (January 2012), http://www.census.gov/prod/cen2010/briefs/c2010br-10.pdf (observing that the Tohono O'odham has one of the smallest populations of those included in the 2010 Census).

${ }^{22}$ See The Official Website of the Tohono O'odham Nation: History and Culture.

${ }^{23}$ See Susan Bradford, Illegal Immigration from the Perspective of Arizona's Tohono O'odham Nation, Aug. 26, 2010, http://susanbradfordpress.wordpress.com/2010/08/26/illegal-immigrationfrom-the-perspective-of-arizonas-tohono-oodham-nation/.

${ }^{24}$ See Dougherty, supra note 17 (amounting to only 33 percent of the U.S. average and far below the $\$ 13,000$ average for Native American tribes).

${ }_{25}$ See Eric Eckholm, In Drug War, Tribe Feels Invaded by Both Sides, The New York Times, Jan. $25,2010$.

${ }^{26}$ See Hugh Holub, Tohono O’odham Reservation Deadly Place for Migrants, Tuscan Citizen. COM, Sept. 2, 2010, http://tucsoncitizen.com/view-from-baja-arizona/2010/09/01/tohonooodham-deadly-place-for-migrants/. Although the Tohodo O'odhams sympathize with the migrants, the number of migrants and associated violence they bring has forced the Tribe to defend themselves by barring water stations and relief groups from entering the reservation. See id. It should be noted that, while border security does exist on the region, the high number of illegal immigrants on tribal land are likely to continue until security is on par with the rest of the Arizona border. See id.

${ }^{27}$ See Dougherty, supra note 16 (indicating that as many as 1,500 migrants pass through the reservation per day). Compare with Immigration in Arizona: Fact Sheet (2012), Federation for American Immigration Reform, April 2012, http://www.fairus.org/issue/immigration-inarizona-fact-sheet (reporting that nearly half of all border crossing occur along the MexicoArizona border). The study also reported that, "From 2001 to 2010, an average of 1,374 illegal aliens a day were apprehended in the Arizona border sector. DHS does not know how many 
both illegal immigration and drug trafficking. ${ }^{28}$ Not only have illegal crossings increased, but migrants are now far more dangerous. ${ }^{29}$ Unable to enjoy the peace and security it once enjoyed, the Tribe must now contend with land "swarming with outsiders, where residents are afraid to walk in the hallowed desert, and some members, lured by drug cartel cash in a place with high unemployment, are ending up in prison. ${ }^{.{ }_{30}}$ Many tribal members have been bribed into smuggling marijuana through the reservation, some of whom end up in prison. ${ }^{31}$ This problem is exacerbated by the fact that in some remote areas, police may not arrive for hours. ${ }^{32}$ In 2009, 319,000 pounds of marijuana were seized on the reservation..$^{33}$ In 2003 and 2004, more than one hundred tribal members were arrested on drug-related charges. ${ }^{34}$

In addition to their fear of drug smugglers, Tribe members also resent federal agents' random and occasionally humiliating searches..$^{35}$ As more illegal migrants' have crossed the reservation, the number of federal and state border control agents on reservation land has increased. ${ }^{36}$ Such changes have meant tighter controls and more checkpoints, making it difficult for the 1,500 tribal members in Mexico to reach important facilities and unite with family members on the American side. ${ }^{37}$ In fact, for many tribal members in Mexico,

illegal aliens successfully entered Arizona each day during that period" (Concluding that the average number of crossings in Arizona nearly equals the highest number of crossings on tribal land; for this reason, the majority must therefore occur on reservation land).

${ }^{28}$ See Andrea Filzen, Clash on the Border of the Tohodo O'odham Nation, Pulitzer Center, Feb. 22, 2013, http://pulitzercenter.org/reporting/clash-border-tohomo-o\%E2\%80\%099odham-na tion-migration-Mexico-Arizona-Native-Americans (reporting that, consequently, the O'odham "way of life as well as O'odham attitudes towards undocumented migrants" has been altered).

${ }^{29}$ See id. (Arguing that in past years, migrants only requested basic necessities such as food and water from the Tribe). Now, "it has gotten pretty dangerous, where there are more people crossing and they want more than water and food-for example, your truck or things on your lawn, and to that extent, Tohono O'odham people are not open to helping because they don't know who they're helping and that might cause further problems." See id. (Quoting Ofelia Zepeda, professor of linguistics at the University of Arizona).

30 See Eckholm, supra note 25.

31 See id. (As Ned Norris, the tribal chairman, stated "Drug smuggling is a problem we didn't create, but now we're having to deal with the consequences").

${ }^{32}$ See id.

33 See id. (Also noting that "hundreds of tribal members have been prosecuted in federal, state, or tribal courts for smuggling drugs or humans, taking offers that reach $\$ 5,000$ for storing marijuana or transporting it across the reservation").

${ }^{34}$ See John Dougherty, One Nation, Under Fire, High Country News, Feb. 19, 2007, http:// www.hcn.org/issues/340/16834.

35 See Eckholm, supra note 25.

${ }^{36}$ See id. See also Cherokee Nation v. Georgia, 30 U.S. 2. Due to the Treaty of Hopewell, the Court has held that the Tribe had given up partial autonomy and was a domestic, dependent nation, dependent upon the federal government as a ward to its guardian. As a result, federal and state law enforcement has a right to enter tribal land to protect individuals.

37 See id. 
access to medical, educational and social services on their reservation in the United States is essential. ${ }^{38}$

Even with these concerns, however, many Tribe members agree that not enough is being done by the federal government to stop illegal immigration. ${ }^{39}$ Migrants not only demand provisions from the Tribe, they also frequently steal tribal possessions like clothes, food, electronics and bicycles. ${ }^{40}$ Tribal members are frequently robbed, have their cars stolen and homes burglarized. ${ }^{41}$ Items of historic and cultural significance are often vandalized. ${ }^{42}$ Elderly tribal members now avoid walking in the desert, even in daytime. ${ }^{43}$ These individuals have abandoned cultural rituals, such as the ingestion of traditional foods for fear of harm. ${ }^{44}$ Verna Miguel, sixty-three years old, says she no longer enters the desert after she was stopped three years ago by a group of migrants, beaten, and had her car stolen. ${ }^{45}$

While federal officials view their work and increased presence as a necessity, many tribal members resent their presence. ${ }^{46}$ Many tribal members criticize the Border Patrol's abuse and cultural ignorance. ${ }^{47}$ Despite these allega-

38 See Dougherty, supra note 34. Because Mexico does not recognize the Tohono O'odham Nation, it does not provide social service for Tribe members. Members also frequently cross the border "to perform sacred ceremonies, visit summer homes, hunt and collect herbs and plants" (explaining necessity of border crossing for Mexican Tohono O'odham members).

${ }^{39}$ See Brady McCombs, O'odham Leader Vows No Border Fence, Arizona Daily Star, Aug. 19, 2007, http://azstarnet.com/news/local/border/o-odham-leader-vows-no-border-fence/arti cle_42e728a3-4314-5efb-a500-8d3c4b6a4b4b.html (stating that "the problem of illegal immigration is a problem of the United States of America. It's not the Tohono O'odham Nation's problem").

${ }^{40}$ See Dougherty, supra note 34 (reporting that "nothing on the reservation, it seems, is safe from being stole - clothes, food, vehicles, cell phones, electronics and, increasingly, bicycles, which allow immigrants to cross the desert more quickly than hiking would").

${ }^{41}$ See Andrea Filzen, Clash on the Border of the Tohono O'odham Nation, Clash on the Border of the Tohodo O'odham Nation, Pulitzer Center, Feb. 22, 2013, http://pulitzercenter.org/reporting/clash-border-tohomo-o $\%$ E2\%80\%99odham-nation-migration-Mexico-Arizona-NativeAmericans.

${ }^{42}$ See Susan Bradford, Illegal Immigration from the Perspective of Arizona's Tohono O'odham Nation, Aug. 26 2010, http://susanbradfordpress.wordpress.com/2010/08/26/illegal-immigrationfrom-the-perspective-of-arizonas-tohono-oodham-nation/. As one Tribe member stated, "the drug runners are destroying our reservation, sacred sites and [vandalizing indigenous pictographs]."

${ }^{43}$ See Eckholm, supra note 25.

${ }^{44}$ See id.

45 See id.

${ }^{46}$ See id. (Reporting that the once tranquil reservation now feels like a "militarized zone"). Barriers and surveillance have forced most of the smugglers to enter on foot, making them more vulnerable to detection. See id. (Noting the increase in border patrol success, "but the large busts... are also a measure of the continued trade and profits reaped by the cartels").

47 See Dougherty, supra note 34. One Tribe leader stated, "Abuse of the people increased. The Border Patrol would hold them at gunpoint and sometimes run them off the road." See id. 
tions, however, the Tribe acknowledges that they have neither the resources nor expertise to prevent illegal border crossings. ${ }^{48}$ Although it has received funding from the Department of Homeland Security, there has not been adequate reimbursement for tribal costs. ${ }^{49}$ With as many as 1,500 migrants crossing tribal lands each day, the lives of some tribal members are constantly interrupted. ${ }^{50}$ The Tohono O'odham Tribe widely criticizes the inadequate efforts realized by the Border Patrol to restore peace and order. ${ }^{51}$

In addition to the violence and criminal effects of migrants' drug-trafficking, these border crossings also create enormous environmental problems that the Tribe must ultimately resolve. ${ }^{52}$ For example, in 2005 more than 1,400 abandoned or wrecked vehicles were towed off the reservation. ${ }^{53}$ It is also estimated that each migrant leaves behind more than eight pounds of litter amounting to 13,000 pounds per day. ${ }^{54}$ Furthermore, the Tribe has criticized the Border Patrol as being disrespectful of tribal lands, as they too often fail to remedy damages caused by their pursuit of illegal migrants. ${ }^{55}$ Not only does the Border Patrol "make their own roads and go wherever they want to go," but they have been known to disturb archeological sites. ${ }^{56}$ Worse

${ }^{48}$ See Eckholm, supra note 25. See also Bradford, supra note 42. As one Tribe member stated, the Tribe has had to invest millions of dollars, money that they do not have, in tribal police to protect against immigrant drug traffickers for which has not been compensated by the federal government. See id.

49 See Brady McCombs, O’odham Leader Vows No Border Fence, Arizona Daily Star, Aug. 19, 2007, http://azstarnet.com/news/local/border/o-odham-leader-vows-no-border-fence/ar ticle_42e728a3-4314-5efb-a500-8d3c4b6a4b4b.html (observing that, in 2007, the Tribe received one million dollars from the Department of Homeland Security and spent three million).

${ }^{50}$ See Dougherty, supra note 34 (as one tribal member explained, "they come at all hours of the day and night. They pound on your windows asking for food and water").

51 See id. In 2004, the Tohono O'odham police reported that 111,264 immigrants entered the reservation, with 84,010 arrested by either the police or Border patrol (quoting Tribes reactions as "if this was happening in Tucson, or any other metropolis, a state of emergency would be declared").

${ }^{52}$ See id. (Stating, for example, that the Tribe has removed more than eighty tons of trash from 128 sites from 2004 until 2007).

${ }^{53}$ See id. (Reporting that thousands of cars, usually stolen from nearby cities, are used to transport migrants and drugs across the reservation). See also Dougherty, supra note 34. (Noting that more than 3,000 bicycles have been found abandoned in the northern and eastern parts of the reservation).

${ }^{54}$ See Paul Cicala, Immigrants Leaving Mounds of Trash on Tohono O'odham Indian Sacred Lands, TuscanNewsNow.com, Nov. 27, 2002, http://www.tucsonnewsnow.com/Global/story.asp?S $=1029934$ (noting that this amounts to almost five million pounds of waste per year).

55 See Brady McCombs, O'odham Leader Vows No Border Fence, O'odham Leader Vows No Border Fence, Arizona Daily Star, Aug. 19, 2007, http://azstarnet.com/news/local/border/oodham-leader-vows-no-border-fence/article_42e728a3-4314-5efb-a500-8d3c4b6a4b4b.html.

56 See Dougherty, supra note 34 (quoting one Tribe member's view of recent Border Patrol behavior). 
still, the Tribe regularly encounters migrant corpses rotting in the desert, as more migrant remains are found on the reservation than any other part of the Arizona-Mexico border. ${ }^{57}$ Tribal members say that these health and environmental issues might take decades, if not longer, to repair. ${ }^{58}$ As a result of the danger and destruction posed by migrants, the federal government needs to increase its efforts to protect the traditional lifestyle once enjoyed by the Tohono O'odham Nation..$^{59}$

On the other hand, Tribal Chairman Ed Norris urges the Border Control to work with the Tribe to reach solutions, rather than imposing changes made without their consent. ${ }^{60}$ Many tribal members view the Department of Homeland Security as inconsiderate of tribal sovereignty and other issues. ${ }^{61}$ "We want to be at the table with them. We want to be able to participate in the decisions that are being made that are going to impact us as a people, impact our land, impact anything that's going to happen as a Nation." ${ }_{62}$ Overall, however, the Tribe hopes to see increased enforcement efforts at the border to combat the source of the problem, not just clean up the effects. ${ }^{63}$

As Mr. Norris stated, "I hope in my lifetime we can go back to the way it used to be, where people could go and walk in the daylight on our own land." Many tribal members worry that the corruption and influence of the migrants have caused the Tribe to lose touch with its culture and historical

${ }^{57}$ See Todd Miller, Shadow Wolves, Border Militarization, and the Tohono O'odham Nation, NACLA, June 22, 2011, https://nacla.org/blog/2011/6/22/shadow-wolves-border-militarizationand-tohono-oodham-nation.

58 See Dougherty, supra note 34. See also Bradford, supra note 42. As one Tribe member stated, "the real problem is that the federal government is failing to properly secure the border."

59 See Eric Eckholm, supra note 26. See also Miller, supra note 57. To date, the Tribe has supported "on-reservation immigration checkpoints, integrated radar and camera systems, surveillance towers, local police and DHS protection and limited National Guard deployment."

${ }^{60}$ See Brady McCombs, O'odham Leader Vows No Border Fence, O’odham Leader Vowes No Border Fence, Arizona Daily StaR, Aug. 19, 2007, http://azstarnet.com/news/local/border/oodham-leader-vows-no-border-fence/article_42e728a3-4314-5efb-a500-8d3c4b6a4b4b.html.

${ }^{61}$ See Andrea Filzen, Clash on the Border of the Tohono O'odham Nation, Pulitzer Center, Feb. 22, 2013, http://pulitzercenter.org/reporting/clash-border-tohomo-o\%E2\%80\%99odhamnation-migration-Mexico-Arizona-Native-Americans. As O'odham police officer Brown reports, "A lot of them don't understand sovereignty issues, they don't understand reservations, they don't understand any of it so they come out here thinking that they, you know, pretty much are untouchable... they started to be resented when Border Patrol stops tribal members to see if they are illegal immigrants. We're both brown. We look a lot alike." See id.

${ }^{62}$ Brady McCombs, O'odham Leader Vows No Border Fence, Arizona Daily Star, Aug. 19, 2007, http://azstarnet.com/news/local/border/o-odham-leader-vows-no-border-fence/arti cle_42e728a3-4314-5efb-a500-8d3c4b6a4b4b.html (quoting Mr. Norris).

63 See Dougherty, supra note 34 (quoting one Tribe member as stating "We would prefer that the Border Patrol and National Guard stay at the border and send migrants away before they cross over. We really feel strongly about this").

${ }^{64}$ Eckholm, supra note 25. 
teachings. ${ }^{65}$ As one member stated, "If these things are not done, we will be lost as a people." ${ }^{\prime 6}$

\section{Analyzing Tohono O'odham Claims against the Federal GOVERnMENT}

The federal trust relationship, as described below, was established as the result of three significant Supreme Court cases during the nineteenth century. ${ }^{67}$ As a result, the Tohono Tribe may have a claim for statutory relief for property damage, as well as injunctive relief due to the common law trust claims.

\section{Statutory Claims for Property Damage}

Under current jurisprudence, the Tohono Nation could sue the federal government seeking statutory relief in the form of monetary damages for property damage incurred as the result of migrant activities. ${ }^{68}$

\section{A. Recovery under 18 U.S.C.A. $\S 1160$}

The Tohono O'odham could assert a statutory claim for relief under Pyramid Lake Paiute Tribe of Indians v. Morton ("Pyramid Lake"), ${ }^{69}$ in which the Pyramid Lake Paiute Tribe sued the Secretary of the Interior ("Secretary") contending that a regulation issued by the Secretary improperly diverted water away from Pyramid Lake. ${ }^{70}$ Pyramid Lake is located on tribal property and has historically been a significant resource for the Tribe. ${ }^{11}$ The Tribe argued that the Secretary's action was a breach of its trust responsibility and an abuse of discretion. ${ }^{72}$ The court held that the burden of proof for the diversion of water had to be justified by the Secretary which, in this particular

${ }^{65}$ See Dougherty, supra note 34.

${ }^{6} \mathrm{Id}$.

67 See Cherokee Nation v. Georgia, 30 U.S. 1 (1831); see also Worcester v. Georgia, 31 U.S. 515 (1832); see also United States v. Kagama, 6 S.Ct. 1109 (1886).

${ }^{68}$ See supra notes 38-44 and accompanying text (describing property damages to Tohono O'odham Tribe from migrants).

${ }^{69}$ See generally Pyramid Lake Paiute Tribe of Indians v. Morton, 354 F.Supp. 252 (1972).

70 See id. at 255 (arguing that regulations mandate water be diverted to Truckee-Carson Irrigation District in Nevada).

${ }^{71}$ See id. at 256 (reporting that the Tribe lives on the shores of Pyramid Lake and uses the lake for fishing).

72 See id. at 255 (stating that the Secretary "illegally and unnecessarily" diverted water away from Pyramid Lake). 
case, failed to do so. ${ }^{73}$ In regard to the trust responsibility, the court also stated that the United States "has charged itself with moral obligations of the highest responsibility and trust. ${ }^{74}$ Its conduct, as disclosed in the acts of those who represent it in dealings with the Indians, should therefore be judged by the most exacting fiduciary standards. ${ }^{975}$

Relying on Pyramid Lake as precedent, the Tohono Tribe could sue the federal government for breach of fiduciary duty and trust responsibility under 18 U.S.C.A. $§ 1160 .{ }^{76}$ This statute proclaims the following:

Whenever a non-Indian, in the commission of an offense within the Indian country takes, injures or destroys the property of any friendly Indian the judgment of conviction shall include a sentence that the defendant pay to the Indian owner a sum equal to twice the just value of the property so taken, injured, or destroyed.

If such offender shall be unable to pay a sum at least equal to the just value or amount, whatever such payment shall fall short of the same shall be paid out of the Treasury of the United States. If such offender cannot be apprehended and brought to trial, the amount of such property shall be paid out of the Treasury. But no Indian shall be entitled to any payment out of the Treasury of the United States, for any such property, if he, or any of the nation to which he belongs, have sought private revenge, or have attempted to obtain satisfaction by any force or violence. ${ }^{77}$

Under this statute, the Tohono O'odhams could possibly recover damages to property, such as the cars, homes and other small items that are frequently stolen or damaged from migrant activities. ${ }^{78}$ It may also be possible, although less likely, to recover for damages to tribal property from trash, including many stolen cars and migrant corpses that are left abandoned on tribal property. ${ }^{79}$ For such a claim to be successful, the Tribe would have to argue that their land has been physically damaged or suffered diminished aesthetic value due to waste left behind by migrants..$^{80}$ It should be noted, however, that this

\footnotetext{
${ }^{73}$ See id. at 256 (holding that the Secretary failed to justify the action as a "sound exercise of discretion" under the rational basis test).

${ }^{74}$ Id. (citing Seminole Nation v. United States, 316 U.S. 286, 297(1942); Navajo Tribe of Indians v. United States, 364 F.2d 320 (1966)).

${ }^{75} \mathrm{Id}$. (Concluding that the trust responsibility can provide a basis to sue only if a fiduciary duty is implied).

${ }^{76}$ See Blackfeather v. US, 23 S.Ct. 772 (1903) (reporting text of 18 U.S.C.A. § 1160).

77 See 18 U.S.C.A. $\$ 1160$ (West 2012) (indicating possible statute Tribe could cover damages under).

${ }^{78}$ See supra notes 39-44 and accompanying text (describing property damage to Tohono O'odham property on account of migrants).

${ }^{79}$ See supra notes 51-56 (discussing environmental impact to tribal property as a result of migrant activity).

${ }^{80}$ See 18 U.S.C.A. $\$ 1160$ (West 2012) (denoting language of the applicable statute).
} 
statutory claim cannot be used to force the federal government to increase its border patrol efforts or stop migrants from crossing tribal lands. ${ }^{81}$

Unfortunately, the Tohono O'odhams cannot rely on strong case precedent to support a $\S 1160$ claim for damages. There are only three cases in which an Indian tribe or member has sought to recover damages under $\S$ 1160 , and two of the suits were brought under an earlier version of the statute. $^{82}$ The main distinction is that this earlier version of the statute began by stating "Whenever, in the commission, by a white person, of any crime, offence, or misdemeanor within the Indian country..." (Emphasis added)..$^{83}$

In United States v. Perryman, an Indian sought to recover damages for the value of twenty-three cattle stolen off of his property by an AfricanAmerican. ${ }^{84}$ The Court held that the defendant in this case could not be sentenced under the former statute, as he was not "a white person." ${ }^{85}$ For this reason, a member of the Tohono O'odham nation, as a non-white, could not seek to recover damages under the former version of the statue. ${ }^{86}$ The current statute states that Indians may recover damages to property as a result of non-Indian activities. ${ }^{87}$ Consequently, Indians can bring claim not just against whites, but against any race or background, including migrants of Hispanic origin.

${ }^{81}$ See Rodina Cave, Simplifying the Indian Trust Responsibility, 32 ArIZ. ST. L.J. 1399, 1415-16 (2000) (However, monetary damages provide inadequate relief).

${ }^{82}$ See 18 U.S.C.A. $\$ 1160$ (West 2012) (laying out terms of statute).

${ }^{83}$ See United States v. Perryman, 100 U.S. 235 (1879) (reporting the full statute as the following: "Whenever, in the commission, by a white person, of any crime, offence, or misdemeanor within the Indian country, the property of any friendly Indian is taken, injured, or destroyed, and a conviction is had for such crime, offence, or misdemeanor, the person so convicted shall be sentenced to pay to such friendly Indian to whom the property may belong, or whose person may be injured, a sum equal to twice the just value of the property so taken, injured, or destroyed"). The accompanying section of the statute prevents Indians from recovery of damages if the individual Indian or tribe has sought revenge for the act. See also id. (Reporting related statute limiting recovery).

${ }^{84}$ See id. at 236 (describing how both an African-American and a white man stolen cattle from the claimant). The white man's charge was dropped, while the African American was found guilty of the offense and imprisoned. See id. (Reporting procedure).

${ }^{85}$ Id. at 238 (holding this interpretation is consistent with Congressional intent). "We cannot but think that Congress meant just what the language used conveys to the popular mind... It was, no doubt, thought if the United States made themselves liable only for such depredations as were committed by the whites, these and other Indians would be less likely to tolerate fugitive blacks in their country. Hence, as a means of preventing the escape of slaves, the change in the law was made. Although the reason of the change no longer exists, Congress has seen fit to keep the law as it was" (concluding African-Americans and other non-white cannot be liable under statute).

${ }^{86}$ See id. (Holding that claimant cannot recover unless he is within statutory terms).

${ }^{87}$ See $\$ 1160$ (implicating "Whenever a non-Indian, in the commission of an offense within the Indian country takes, injures or destroys the property of any friendly Indian” language). 
The second case that may be relevant to a claim under $\S 1160$ is Blackfeather v. United States ${ }^{88}$ in which an Indian sought to recover damages for destruction and theft of livestock and other personal property that was taken by United States citizens and soldiers during the Civil War era. ${ }^{89}$ The Court analyzed the Indian's claim under both the predecessor to $\S 1160$ and a treaty signed with the Shawnee Tribe, of which the claimant was a member..$^{90}$ The Court held that the language implicated by the applicable treaties conferred a claim for damages for the Tribe as a whole, not individual members of the Tribe. ${ }^{91}$ Therefore, because the Court reached its holding based on treaty language alone, it is still possible for an individual member of a tribe, such as the Tohono O'odham, to bring a statutory claim by relying solely on statutory language..$^{92}$ It is important to note, however, that the applicable language here is almost identical to the statute's current version--unlike the language used

${ }^{88}$ See generally Blackfeather v. US, 23 S.Ct. 772 (1903).

${ }^{89}$ See id. at 733 (reporting that "The petitioner asks to recover and collect from the United States the several amounts of money thereafter set out at length in payment for the destruction, loss, forcible taking, carrying, and driving away of livestock, farm products, household goods, money, and other personal property of divers descriptions and kinds belonging to, owned, and possessed by, and the property of, the said Shawnee Indians, by white and United States citizens and soldiers, in the state of Kansas and the Indian territory, at divers times and places in the year 1861, and all the time up to and including the year 1866... [for] varying in amounts from as high as $\$ 7,000$ down to $\$ 75$, and aggregating $\$ 530,945.14 ”)$.

${ }^{90}$ See id. (Describing how Shawnee Nation claimed damages under articles 11 and 14 of the treaty of May 10, 1854 (10 Stat. at L. 1053, 1057). Article 11 provides a means of compensation for property damage. See id. ("All Shawnees who have sustained damage by the emigration of citizens of the United States, or by other acts of such citizens, shall, within six months after the ratification of this treaty, file their claims for such damages with the Shawnee agent, to be submitted by him to the Shawnee council, for their action and decision, and the amount in each case approved shall be paid by said agent: Provided, the whole amount of claims thus approved shall not exceed the said sum stipulated for in this article. And provided, that if such amount shall exceed that sum, then a reduction shall be made pro rata from each claim until the aggregate is lowered to that amount. If less than that amount be adjudged to be due, the residue, it is agreed, shall be appropriated as the council shall direct"). Article 14 mandates that the tribe acknowledge its dependence on the United States and abide by its laws. See id. ("The Shawnees acknowledge their dependence on the government of the United States, and invoke its protection and care. They will abstain from the commission of depredations and comply, as far as they are able, with the laws in such cases made and provided, as they will expect to be protected and to have their rights vindicated").

${ }^{91}$ See id. at 378 (concluding that, "We see nothing in the act... appropriating moneys for the payment of 'claims of certain members of the Shawnee Tribe of Indians,' which affects the conclusion we have reached that the [acts] refer to tribes, and not individuals. The act of 1860 appropriates, in terms, money to pay claims of certain members of the tribe. It is apparent that when Congress intends to include individuals as distinct from tribes, it does not speak of them as Shawnee Indians, but as 'certain members' of the Shawnee tribe"). The Court also notes that the legislature is free to make changes to such language. See id.

${ }^{92}$ See id. (Noting reliance on treaty language in analysis). 
in United States v. Perryman..$^{93}$ It is therefore still possible for an individual member of the Tohono O'odham Tribe to successfully sue under $\S 1160$ to recover personal property damages from migrants.

One additional feature of $\S 1160$ claims for damages resulted from Coosewoon v. Meridian Oil Co ${ }^{94}$ in which the plaintiff brought a claim against the Secretary and an oil company alleging negligence in the payment of oil and gas royalties on Indian land. ${ }^{95}$ At issue in Coosewoon is the following $§ 1160$ provision: "Whenever a non-Indian, in the commission of an offense within the Indian country takes, injures or destroys the property of any friendly Indian the judgment of conviction shall include a sentence of..." (Emphasis added)..$^{96}$ The plaintiff argued that a violation of $\S 1160$ creates an automatic claim of negligence per se. ${ }^{97}$ However, the court held that $\S 1160$ is merely a sentencing provision, stating that " $[\mathrm{It}][\mathrm{d}]$ oes not proscribe conduct but instead enhances the sentence of one who has engaged in conduct proscribed by other criminal statutes. ${ }^{98}$ Although this may seem detrimental to a Tohono O'odham claim, it is simply a procedural formality. Based on this language, it can be inferred that a prior conviction under a distinct statute of the same criminal defendant is not necessarily a prerequisite. On the contrary, by only requiring that defendants engage in outlawed conduct, it is possible to assert a $\$ 1160$ claim along with many other charges against migrants in order to recover property damages. Such indictments could include any of the following, among others: larceny, burglary, bribery, drug smuggling, assault, intimidation, criminal mischief, public health violations, disturbing the peace, theft of items of cultural significance, and a wide range of environmental violations. ${ }^{99}$

It is also important to note that Coosewoon v. Meridian Oil Co. fails to incorporate the second part of $\S 1160$, under which an Indian may recover damages from the federal government if the perpetrator cannot be appre-

${ }^{93}$ See 18 U.S.C.A. $\$ 1160$, supra note 87. Compare with United States v. Perryman, 100 U.S. 235 (1879) (laying out earlier version of 18 U.S.C.A. $§ 1160$ ).

${ }^{94}$ See generally Coosewoon v. Meridian, 25 F.3d 920 (10 Cir. Ct. App. 1994) (noting third case that cites 18 USCA $\S 1160)$. This case analyzes $\S 1160$ as to whether it establishes a claim of negligence per se. The court held that is does not, as the statute is merely a sentencing provision. However, the court does not discuss the merits of whether the plaintiffs have a claim for damages under $\S 1160$ because the plaintiff must first demonstrate a violation of conduct prescribed by other statutes. See id. at 926 .

${ }^{95}$ See id.

96 See 18 U.S.C.A. $\$ 1160$ (West 2012) (emphasis added).

${ }_{97}$ See Coosewoon v. Meridian, 25 F.3d 920, 925(reporting that Plaintiffs contended the "district court erred in dismissing Count $\mathrm{V}$ of their complaint which alleged Meridian committed negligence per se through its alleged violation of 18 U.S.C. $\$ 1160$ ").

${ }^{98}$ Id. at 926 (concluding that $\$ 1160$ "provided an improper basis for plaintiff's negligence per se claim").

99 See, e.g., 10 U.S.C.A. $§ 921$ (citing federal larceny statute). However, many of these claims are unique to state law. In Arizona, where the Tohono O'odham reside, one can sue for assault, for example, under A.R.S. § 13-1203. 
hended. ${ }^{100}$ This provision only reinforces the assertion that the holding in Coosewoon v. Meridian Oil Co. must mean that a prior conviction is unnecessary. ${ }^{101}$ Otherwise, such a holding would make the second paragraph of $\S$ 1160 superfluous, as it is highly unlikely that a defendant would be convicted of property theft or damage without being accused of a $\S 1160$ violation.

For the above reasons, the Tohono O'odham Nation cannot rely on strong case precedent to support a $\S 1160$ claim, as only three cases in the statute's history specifically address claims for relief under this statute. As discussed below, however, the tribe can sue for monetary and equitable relief under other case precedent.

\section{B. Statutory Relief under the case Mitchell II}

The Tohono O'odham Nation could also sue for monetary relief under $\S$ 1160 and the statutory analysis established in Mitchell II. The seminal case for Mitchell II claims is United States v. Navajo Nation, which does not preclude a suit for property damage compensation under $\S 1160 .{ }^{102}$ At issue was whether the United States breached its fiduciary duty, via the Indian Mineral Leasing Act ("IMLA"), to the Navajo Tribe by failing to re-negotiate its coal leases to secure a higher rate of return. ${ }^{103}$ In its decision, the Court relied on Mitchell II, which held that a "network of other statutes and regulations did impose judicially enforceable fiduciary duties upon the United States in its management of forested allotted lands. ${ }^{\prime 104}$ Mitchell II acknowledged this duty by contrasting the "bare trust created by the [General Allotment Act]" to comprehensive timber management statutes. ${ }^{105}$ Navajo Nation, on the other hand, held that the fiduciary responsibility by the federal government under IMLA did not allow for private monetary damages, as it only required the Secretary's approval for Tribe's mining leases. ${ }^{106}$ The Court further held that

${ }^{100}$ See 18 U.S.C.A. $\S 1160$ (West 2012).

101 See id. and accompanying text (arguing that $\S 1160$ is merely a sentencing provision).

${ }^{102}$ See generally US v. Navajo, 537 U.S. 488 (2003).

${ }^{103}$ See id. at 488 (stating that the Tribe alleged the Secretary's approval of coal mining leases between the Tribe and Peabody Coal Company constituted a breach of trust). The Tribe sued the federal government for $\$ 600$ million in damages. See id. at 500 .

${ }^{104}$ US v. Mitchell, 463 U.S. 206, 224 (1983) (concluding that the "statutes and regulations now before us clearly give the federal government full responsibility to manage Indian resources and land for the benefit of the Indians").

${ }^{105}$ Id. at 226 (holding that because the statutes in Mitchell II establish a fiduciary duty, "they can fairly be interpreted as mandating compensation by the Government for damages sustained. Given the existence of a trust relationship, it follows that the Government should be liable in damages for the breach of its fiduciary duties").

${ }^{106}$ See US v. Navajo, 537 U.S. 488, 506 (noting that the IMLA "simply requires Secretarial approval before coal mining leases negotiated between Tribes and third parties become effective..."). 
the IMLA was more consistent with Mitchell I, which seeks to enhance tribal self-determination. ${ }^{107}$ In Navajo Nation, the IMLA gave the tribes, not the federal government, the leading role in negotiating coal leases. ${ }^{108}$ Imposing fiduciary duties would thus be contrary to the statute's main purpose.

Here, Navajo Nation does not preclude a $\$ 1160$ claim because this statutory provision is more similar to the fiduciary duty imposed on the United States in Mitchell II than the administrative requirements stipulated in Navajo Nation. ${ }^{109}$ Although $\S 1160$ does not does not implicate a complicated web of statues and regulations as is indicative of a Mitchell II analysis, it nevertheless imposes a similar affirmative duty by the federal government to compensate for property damage. ${ }^{110}$ Moreover, $\S 1160$ is inconsistent with Mitchell I and Navajo Nation as the purpose of this statute is to compensate for property damage suffered by Indians, not to increase tribal sovereignty. ${ }^{11}$ In fact, $§ 1160$ decreases tribal autonomy as it implicitly acknowledges that tribes are not themselves capable of either preventing trespassers from entering their land or absorbing the cost of damages caused by such individuals. A $\S 1160$ claim brought by the Tohono O'odhams must therefore rely on Mitchell II as controlling precedent.

United States v. White Mountain Apache solidifies the concept that a potential claim for damages should be brought under a Mitchell II analysis. ${ }^{112}$ Here, tribal land was held in trust by the federal government, which had allowed the buildings and property to deteriorate over many years. ${ }^{113}$ The Court held that the federal government had a duty to maintain the property and could not let it "fall into ruin on [it's] watch." ${ }^{114}$ In its holding, the court

${ }^{107}$ See id. at 507 (arguing that Mitchell I not only did not authorize, but did not even require government action in managing timber resources).

108 See id. at 508 (noting that the "IMLA aims to enhance tribal self-determination by giving Tribes, not the Government, the lead role in negotiating mining leases with third parties"). See id. (Comparing with Mitchell I, where the General Allotment Act was designed so that the tribe, not the government, would manage the land).

109 See US v. Navajo, 537 U.S and accompanying text (observing web of statutes and regulations giving rise to a fiduciary duty on part of federal government). Compare with supra note 109 and accompanying text (noting mere administrative requirements imposed by IMLA).

${ }^{110}$ See $\$ 1160$ (noting right of compensation for property damages).

111 See Id. (concluding that Mitchell I and Navajo Nation aim to increase tribal autonomy). Section 1160, on the other hand, aims to compensate for damages by non-Indians through federal government payments.

112 See generally United States v. White Mountain Apache, 537 U.S. 465 (2003) (holding that, "the United States' breach of fiduciary duty to maintain and preserve trust property gave rise to substantive claim for money damages under the Indian Tucker Act").

${ }^{113}$ See id. at 469 (reporting that, "Although the National Park Service listed the fort as a national historical site in 1976, the recognition was no augury of fortune, for just over 20 years later the World Monuments Watch placed the fort on its 1998 List of 100 Most Endangered Monuments").

${ }^{114}$ Id. at 475. 
relied on a Mitchell II argument that the act granting trust of the property to the federal government was sufficient to impose a duty to compensate for damages caused to tribal land and property. ${ }^{115}$

Finally, the Tohono O'odhams could sue the federal government for breach of trust under 18 U.S.C.A. § 1165, which allows Indians to recover damages caused by trespassers who unlawfully take "game, fish, and peltries" from tribal land. ${ }^{116}$ Although filing such a suit remains an option, it is unlikely given the lack of evidence that such crimes commonly occur on the Tohono O'odham reservation.

\section{The Guardian Ward Relationship: Common Law Trust and Protection Claim}

The Tohono O'odham could seek equitable relief under the common law of trusts. Such a claim is the modern manifestation of the evolution of the historic guardian-ward relationship between the federal government and the Indian tribes.

\section{A. History of the Guardian-Ward Relationship}

The Guardian-Ward relationship between the federal government and the Native American tribes has undergone significant change since it was established. The foundation of this relationship was first articulated in Cherokee Nation v. Georgia. ${ }^{117}$ Here, the Cherokee Nation sought an injunction against Georgia to prevent it from taking Cherokee land and enforcing state law on the Cherokee reservation. ${ }^{118}$ The Supreme Court declined to rule on the merits, instead stating that it lacked jurisdiction given that the Cherokee Nation is

115 See id. at 475 (concluding that "The 1960 Act goes beyond a bare trust and permits a fair inference that the Government is subject to duties as a trustee and liable in damages for breach"). Furthermore, "as to the property subject to the Government's actual use, then, the United States has not merely exercised daily supervision but has enjoyed daily occupation, and so has obtained control at least as plenary as its authority over the timber in Mitchell II." See id. at 476 .

${ }^{116}$ See 18 U.S.C.A. $\$ 1165$ ("Whoever, without lawful authority or permission, willfully and knowingly goes upon any land that belongs to any Indian or Indian tribe, band, or group and either are held by the United States in trust or are subject to a restriction against alienation imposed by the United States, or upon any lands of the United States that are reserved for Indian use, for the purpose of hunting, trapping, or fishing thereon, or for the removal of game, peltries, or fish therefrom, shall be fined under this title or imprisoned not more than ninety days, or both, and all game, fish, and peltries in his possession shall be forfeited").

117 See generally Cherokee Nation v. Georgia, 30 U.S. 1 (holding that tribes are subject to Guardian-Ward relationship with federal government).

118 See id. at 3 (reporting that Cherokees sought to prevent Georgia from "executing and enforcing the laws of Georgia or any of these laws, or serving process, or doing anything towards 
a type of "dependent nation." "119 Based on the Treaty of Hopewell, the Court held that the Tribe had given up partial autonomy and was a "domestic, dependent nation" dependent upon the federal government as a ward to its guardian. ${ }^{120}$

One year later in 1832, the Supreme Court further defined the scope of tribal autonomy in Worcester v. Georgia, ${ }^{121}$ in which it held that a Georgia statute prohibiting non-Indians from entering Indian territory without a license was unconstitutional. ${ }^{122}$ As a result of federalist claims, only the federal government, not state governments, can regulate Indian affairs. ${ }^{123}$ In reaching this conclusion, however, the Court argued that tribes are a distinct, self-governing body with exclusive authority to promulgate laws within its borders. ${ }^{124}$ Moreover, this authority comes from the tribe's natural rights. ${ }^{125}$

Finally, in the United States v. Kagama, the Supreme Court established the plenary power doctrine, ${ }^{126}$ expanding the guardian-ward relationship by upholding the Constitutionality of the Major Crimes Act. ${ }^{127}$ This case held that even though the Constitution failed to grant Congress plenary power,

the execution or enforcement of those laws, within the Cherokee territory, as designated by treaty between the United States and the Cherokee nation").

119 See id. at 11 (declaring that "original jurisdiction of controversies between a state and a foreign state, without any restriction as to the nature of the controversy; that, by the constitution, treaties are the supreme law of the land. That as a foreign state, the complainants claim the exercise of the powers of the court of protect them in their rights, and that the laws of Georgia, which interfere with their rights and property, shall be declared void, and their execution be perpetually enjoined").

${ }^{120}$ See id. at 2 (describing domestic, dependent nations as "unquestionable, and heretofore an unquestioned right to the lands they occupy, until that right shall be extinguished by a voluntary cession to our government... Their relations to the United States resemble that of a ward to his guardian. They look to our government for protection; rely upon its kindness and its power; appeal to it for relief to their wants; and address the President as their great father").

${ }^{121}$ See generally Worcester v. Georgia, 31 U.S. 515 (1832)(holding Indians have exclusive discretion to govern within their territories).

${ }^{122}$ See id. at 558 (holding that "So long as treaties and laws remain in full force, and apply to Indian nations, exercising the right of self-government, within the limits of a state, the judicial power can exercise no discretion in refusing to give effect to those laws, when questions arise under them, unless they shall be deemed unconstitutional").

${ }^{123}$ See id. (Concluding that, due to the American victory over Great Britain, power to regulate Indian affairs passed to the federal government, not states).

${ }^{124}$ See id. at 519 (arguing that "nation" means a "people distinct from others").

125 See id. (Concluding that "The Indian nations had always been considered as distinct, independent political communities, retaining their original natural rights, as the undisputed possessors of the soil, from time immemorial").

${ }^{126}$ See generally United States v. Kagama, 6 S.Ct. 1109 (1886).

${ }^{127}$ See id. at 379 (stating that the power to establish laws over Indians derives from "the ownership of the country in which the territories are, and the right of exclusive sovereignty which must exist in the national government, and can be found nowhere else"). 
this power also has never been denied as belonging to Congress. ${ }^{128}$ This authority was implicit by the fact that the tribes were considered domestic, dependent nations. ${ }^{129}$

\section{B. The Modern Trust Doctrine: Specific Performance Relief under Common Law}

In addition to seeking statutory relief for property damages, the Tohono O'odhams can pursue equitable relief under a common law breach of trust claim. These trust claims are derived from the Guardian-Ward relationship. ${ }^{130}$ Base on this relationship, as previously discussed, tribes were regarded as dependent nations with the ability to self-govern. ${ }^{131}$ The basis for this relationship still remains unclear, as courts, intellectuals and the government have defined this association to be based on both trust and fiduciary duties. ${ }^{132}$

In any case, this relationship created an obligation of trust on the part of the federal government, which has resulted in several breach of common law trust suits in federal district courts. ${ }^{133}$ In general, when a beneficiary of a trust

${ }^{128}$ See id. at 378 (reporting that the Constitution is "almost silent" concerning government relations with the Indians).

${ }^{129}$ See id. at 384 (arguing that this power is "necessary to their protection, as well as to the safety of those among whom they dwell. It must exist in that government, because it never has existed anywhere else; because the theater of its exercise is within the geographical limits of the United States; because it has never been denied; and because it alone can enforce its laws on all the tribes").

${ }^{130}$ See Rodina Cave, Simplifying the Indian Trust Responsibility, 32 ArIz. ST. L.J. 1399, 1400 (2000) (describing the guardian-ward relationship as a "justification for dispossessing tribes of their lands"). As a contemporary alternative, Indians should invoke the common law of trust to request relief from breaches of trust. See id.

${ }^{131}$ See Cherokee Nation v. Georgia, 30 U.S. 11 (describing tribes' relationship with federal government). See also Worcester v. Georgia, 31 U.S. 519 (describing tribes as a separate people).

132 See Cave, supra note 130, at 1406-07 (citing, for example, the General Allotment Act as establishing a relationship based on trust, while fiduciary responsibility is more of a modern concept). See also Nell Jessup Newton, Enforcing the Federal Indian Trust Relationship After Mitchell, 31 CATH. U.L. Rev. 635, 637 (1982) ("The exact source of this special relationship remains uncertain. Ownership of Indian land, the helplessness of Indian tribes in the face of a superior culture, higher law, the entire course of dealings between the government and Indian tribes, treaties, and hundreds of cases and... a bulging volume of the U.S. Code have all been cited as the source").

133 See Cave, supra note 130, at 1410 (stating that this type of litigation is advantageous because federal judges have more familiarity with breach of trust claims than Indian law claims). See also Richard Ansson, The North American Agreement on Environmental Cooperation and Native American Tribes: How Can Tribal Interests Best Be Protected?, 66 UMKG L. Rev. 837, 857 (1998)(noting that, prior to Mitchell, common law breach of trust cases were common). Although Mitchell encouraged suits to be brought under breach of fiduciary duty, some recent court decisions indicate that breach of trust causes of actions are still available. See id. (Concluding private 
has a complaint against the trustee, such an action can be brought under the common law of trusts. ${ }^{134}$ The common law of trusts provides the beneficiary with a right to relief. ${ }^{135}$ Equitable relief is the most common form of remedy for breaches of trust. ${ }^{136}$ Despite the discovery of widespread mismanagement of tribal fund, however, this form of equitable relief is not usually sought by Indians. ${ }^{137}$

Cobell v. Babbit further supports the possibility of equitable relief based upon a trust relationship. ${ }^{138}$ The plaintiffs in this case were beneficiaries of a trust managed by the federal government, claimed breach of trust under the Indian Trust Fund Management Reform Act ("ITFMRA"). ${ }^{139}$ The court held that the government had violated its trust obligations and ordered equitable relief to the plaintiffs in the form of compliance with accounting and reporting requirements under the ITFMRA. ${ }^{140}$ The court also paved the way for future equitable relief by waiving sovereign immunity for such claims. ${ }^{141}$

In Manchester Band of Pomo Indians, Inc. v. United States ("Manchester Band"), the plaintiffs also sued the federal government for equitable relief,

breach of trust claims may be invoked in the future). However, courts "have not yet resolved what standard will be applied to governmental conduct when the claim is based on the general trust relationship." See id.

${ }^{134}$ See Cave, supra note 130, at 1399 (noting that "centuries of common law trust doctrine have shaped the federal common law of trusts").

${ }^{135}$ See Richard Ansson, The North American Agreement on Environmental Cooperation and Native American Tribes, 66 UMKC L. REv. 837, 858 (1998)(arguing that the trustee has a "duty to protect the trust property against damage or destruction. He is obligated to the beneficiary to do all acts necessary for the preservation of the trust res which would be performed by a reasonably prudent man employing his own like property for purposes similar to those of the trust") (citing Fort Mojave Indian Tribe v. United States, 23 Cl. Ct. 417, 426 (1991)). See Cave, supra note 130, at 1399 (stating that the word "trust" also "raises images of being able to rely on the integrity of someone or to have confidence in that person or in some event").

${ }^{136}$ See Cave, supra note 130, at 1400.

${ }^{137}$ See id. (Describing how the mismanagement of tribal resources is notorious and has been subject to public scrutiny).

${ }^{138}$ See generally Cobell v. Babbitt, 91 F. Supp.2d 1, 7 (D.D.C. 1999) (holding federal government liable for equitable relief under breach of trust claim).

${ }^{139}$ See Cobell v. Babbitt, 91 F. Supp.2d 1, 7 (D.D.C. 1999) (reporting that "The United States... cannot say how much money is or should be in the trust. As the trustee admitted on the eve of trial, it cannot render an accurate accounting to the beneficiaries, contrary to a specific statutory mandate and the century-old obligation to do so").

${ }^{140}$ See id. at 58 (holding that the ITFMRA required the United States to "provide plaintiffs an accurate accounting of all money... retrieve and retain all information concerning the trust... and establish written policies and procedures necessary").

${ }^{141} I d$. at 24 (implicitly allowing future equitable relief claims to be brought). The court stated that, "An action in a court of the United States seeking relief other than money damages and stating a claim that an agency or an officer or employee thereof acted or failed to act in an official capacity or under color of legal authority shall not be dismissed nor relief therein be denied on the ground that it is against the United States." See id. 
alleging/government mismanagement of funds held in trust for dairy farms owned by the Tribe. ${ }^{142}$ Specifically, the Tribe argued that the government failed to invest tribal funds and make interest payments. ${ }^{143}$ The court analyzed the Tribe's claim under the common law of trusts, stating that the "conduct of the Government as a trustee is measured by the same standards applicable to private trustees," and, as a result, the Government must administer the trust "solely in the interest of the beneficiary." mon law of trusts and granted the plaintiffs equitable relief in the form of investment of trust assets at prevailing rates. ${ }^{145}$

Cobell v. Babbit and Manchester Band both establish an avenue for equitable relief based on both tribes' status as a beneficiary of a trust managed by the federal government. Although a small portion of Tohono O'odham land is privately held as a result of the General Allotment Act, most of the land continues to be held in trust by the Federal Government. ${ }^{146}$ The Tribe could therefore pursue equitable relief in the form of an injunction against migrant crossings for the majority of land held in trust by the government. Relying on Cobell v. Babbit as precedent, the tribe could similarly assert a breach of trust claim under the ITFMRA. ${ }^{147}$ The most relevant provision of the ITFMRA states that the trustee has an explicit responsibility to "Appropriately manag $[\mathrm{e}]$ the natural resources located within the boundaries of Indian reservations and trust lands." ${ }_{148}$ The Tribe could therefore make an argument that their natural resources, which include abiotic resources, are being compromised by migrants exploiting these resources on tribal reservations. ${ }^{149}$

${ }^{142}$ See Manchester Band of Pomo Indians, Inc. v. U.S., 363 F. Supp. 1238, 1242 (stating that the Manchester Band of Pomo Indians owned a dairy enterprise and revenues generated were placed in an account managed by the BIA).

143 See id. (Reporting that "during the entire time the dairy enterprise was operative, a period of some eighteen years, only two payments of interest were made to the Band, totaling slightly more than $\$ 26$... Some, but not all, of the interest generated from the Treasury deposits were deposited in commercial banks at prevailing rates of interest").

${ }^{144}$ Id. at 1245 (concluding that, "While it is true that under the terms of the trust, the trustee may be permitted to lend himself money held by him in trust, the trustee violated his duty to the beneficiary if he acts faith, no matter how broad the provisions of the trust may be").

${ }^{145}$ See id. (Holding that, "in the course of prudent management of the affairs of the Indians... the government is under a duty to pay to the plaintiffs the interest thereby lost by them").

146 See Indian Land Tenure Foundation, Allotment Information for Western BIA REGION, 2012, http://www.iltf.org/sites/all/themes/iltf/maps/western.pdf. Currently, only 41,003 acres or approximately 64 square miles of Tohono O'odham reservation have been allotted and therefore held privately. This is only about $1.4 \%$ of the reservation, as the total reservation comprises 4,453 square miles.

${ }_{147}$ See Cobell v. Babbitt, 91 F. Supp.2d, supra note 139 and accompanying text (discussing ITFMRA claim and equitable relief).

14825 USCA $\S 162 \mathrm{a}$ (West 1994).

149 See Abiotic Resource, Biology Online, http://www.biology-online.org/dictionary/Abi otic_resource (stating that abiotic resources include water, land, air and ores). 
The Tohono O'odhams could also assert a claim under Manchester Band for a violation of the private law of trusts. According to this holding, the Government is obligated to act in the tribe's best interest and to administer the trust in the best interest of the beneficiary. ${ }^{150}$ In addition to the case Manchester Band, one article articulates a novel manifestation of this concept, to which the Tohono O'odhams could adequately analogize in support of their relief. This article asserts that, under the federal trust doctrine, the federal government is obligated to assists Indians "in the protection of their property and their rights." ${ }_{151}$ The article discusses the North American Agreement on Environmental Cooperation ("Agreement") and how tribal interests can best be protected through this treaty. ${ }^{152}$ The author argues that the tribes have a clear interest in the Agreement, due to environmental problems involving water, waste and air pollution associated with lax Mexican environmental laws as well as spillage and illegal dumping of hazardous wastes by Mexico entities. ${ }^{153}$ As a result, the federal government should be responsible for protecting reservation land by advocating tribal claims under the Agreement whenever a tribe's land or resources are threatened under its obligations as trustee. ${ }^{154}$

Since the Tohono O'odham Tribe faces a threat to its property and way of life due to Mexican policies, ${ }^{155}$ the federal government as trustee must legally protect tribal property interests. ${ }^{156}$ Here, the Tohono O'odhams could seek equitable relief in the form of an injunction prohibiting specific migrants

${ }^{150}$ See Manchester Band of Pomo Indians, Inc. v. U.S., 363 F. Supp. 1238, 1242 nd accompanying text (describing obligations of federal government as trustee of tribal trusts).

151 Richard Ansson, The North American Agreement on Environmental Cooperation and Native American Tribes: How Can Tribal Interests best Be Protected?, 66 UMKG L. REv. 837, 839 (1998) (arguing that, "in the context of NAFTA, these duties these duties required the United states government to either bring a tribe's claim or to actively support a claim brought by a tribe within the structures created by the [Agreement]").

152 See id. at 861 (discussing that the Agreement was established between the governments of Canada, the United States and Mexico to "enhance compliance with existing environmental laws and to strengthen future environmental protection efforts").

${ }^{153}$ See id. at 845-46 (finding that "Tribes residing along the United States-Mexico border have already experienced problems associated with lax enforcement of Mexican environmental laws... Since the passage of NAFTA, tribal entities have experienced problems associated with the spillage or illegal dumping of hazardous wastes on their land. A 1996 report by the United States General Accounting Office noted that more than 1250 trucks cross daily from Mexico into the United States carrying cargo which exhibited 'significant safety concerns"').

154 See id. (Concluding that, "in order to fulfill the goals of the [Agreement] and his duties as tribal trustee, the United States representative must advocate for a tribe or support a tribe's claim when its land or resources are being environmentally threatened by another party's failure to enforce its environmental laws").

155 See supra notes 29-60 and accompanying text (describing destruction to Tohono O'odham tribe).

156 See Richard Ansson, The North American Agreement on Environmental Cooperation and Native American Tribes: How Can Tribal Interests best Be Protected?, 66 UMKG L. REv. 837, 861 (1998). 
from crossing through tribal land and destroying tribal property. The federal government would be ultimately responsible for complying with such relief under its trust responsibility.

A breach of trust claim is essential to the Tohono O'odham's quest to restore peace to its reservation. Suing for breach of fiduciary duty under $\S$ 1160 , as described above, will only allow the tribe to recover monetary damages for tangible objects. ${ }^{157}$ However, if the Tribe sues for equitable relief in the form of an injunction, it could stop the root of its problems at the source. Such a suit may not be adequately enforced, as the federal government has been clearly unsuccessful in securing the United States-Mexican border for many years. ${ }^{158}$ By pursuing equitable relief, however, the Tohono O'odhams would not only send a message to the federal government that border patrol efforts need to be improved, but also more adequately preserve the culture and integrity of the Tribe. ${ }^{159}$

\section{GonClusion}

Immigration is a significant problem for Americans living in the Southwest, but it is a matter of financial security and cultural integrity for the Tohono O'odham Tribe. Illegal migrants from Mexico have exploited the Tohono O'odham reservation due to its relatively weak border protection, which is the result of a federal government greater efforts to secure the nation's borders on either sides of the tribal reservation, creating a funnel effect. ${ }^{160}$ As a result of the increase in migrant crossings on reservation land, the tribe now faces violence, drug-trafficking, and environmental destruction. ${ }^{161}$ The Tohono O'odham are no longer able to enjoy their relatively serene and traditional lifestyles. ${ }^{162}$

${ }^{157}$ See 18 U.S.C.A. $\$ 1160$ (reporting that, where Indian property is taken by a non-Indian, the Indian is entitled to "a sum equal to twice the just value of the property so taken, injured, or destroyed").

${ }^{158}$ See, e.g., Julia Preston, Huge Amounts Spent on Immigration, Study Finds, The New York Times, Jan. 7, 2013, http://www.nytimes.com/2013/01/08/us/huge-amounts-spent-on-immigration-study-finds.html?_r=0 (reporting on the severity of immigration issues facing the government).

159 See Cave, supra note 130, at 1415-16 (arguing that monetary damages provide inadequate relief). In sum, "tribes have much more at stake than loss of funds. Money is not an adequate substitute... tribes rely on their land base to maintain their cultures and societies. Religious practices in Native religions often require ceremonies to take place in certain areas for the survival of the people and continuation of the world. This is important to the goal of maintaining distinct political society."

${ }^{160}$ See Hugh Holub, Tohono O’odham reservation Deadly Place for Migrants, Tuscan Citizen.com, Sept. 2, 2010, http://tucsoncitizen.com/view-from-baja-arizona/2010/09/01/tohono-oodham-deadly-place-for-migrants/.

${ }^{161}$ See supra notes 30-60 and accompanying text.

${ }^{162}$ See John Dougherty, One Nation, Under Fire, High Country News, Feb. 19 2007, http:// 
As a result of both the tangible and intangible destruction faced by the Tribe on account of undocumented migrants passing through tribal land, and the failure of Border Control to curb such abuse, the Tribe's interests would be best served by suing the federal government. Under $\S 1160$, the Tribe could claim monetary relief to compensate for tangible damage caused by migrants; under the common law of trusts, the Tribe could sue the federal government for equitable relief to encourage the government to take action in preventing the influx of migrants. In either case, it is vital that the Tribe obtain some form of relief to counter the destruction it continues to face. 